\title{
PENINGKATAN KEMAMPUAN GURU DALAM PELAKSANAAN PEMBELAJARAN INOVATIF MELALUI KEGIATAN LESSON STUDY
}

\section{Tiar Delimawati Tambunan}

Pengawas SMA pada Dinas Pendidikan Propinsi Sumatera Utara, Medan. E-mail: tambunantiar@ymail.com

Diterima 23 April 2017, disetujui untuk publikasi 17 Juli 2017

\begin{abstract}
Abstrak Peningkatan mutu pembelajaran di dalam kelas, dimana sekelompok guru bekerja secara kolaboratif dan berkelanjutan untuk memperbaiki mutu pembelajaran. Lesson study yang didisain dengan baik akan menjadikan guru yang profesional dan inovatif. Dengan melaksanakan lesson study para guru dapat menentukan kompetensi yang perlu dimiliki siswa, merencanakan dan melaksanakan pembelajaran yang efektif; mengkaji dan meningkatkan pelajaran yang bermanfaat bagi siswa; memperdalam pengetahuan tentang mata pelajaran yang disajikan para guru; menentukan standar kompetensi yang akan dicapai para siswa; merencanakan pelajaran secara kolaboratif; mengkaji secara teliti belajar dan perilaku siswa; mengembangkan pengetahuan pembelajaran yang dapat diandalkan; dan melakukan refleksi terhadap pengajaran yang dilaksanakan berdasarkan pandangan siswa dan koleganya. Lesson study dapat menjadikan guru sebagai peneliti pembelajaran yang bermanfaat bagi siswa dan dapat meningkatkan aktivitas siswa dalam pembelajaran. Peningkatan aktivitas sebesar 11,09\% dari siklus 1 ke siklus 2. Demikian juga dalam proses pembelajaran mulai pendahuluan, isi, penutup dan penampilan juga meningkat dari siklus 1 ke siklus 2. Jadi Lesson study dapat meningkatkan kemampuan guru dalam pembelajaran dan meingkatkan aktivitas siswa.
\end{abstract}

Kata kunci :

Lesson study, Pembelajaran, inovatif. 


\section{Pendahuluan}

Pendidikan merupakan suatu kegiatan universal yang dilakukan oleh manusia. Dalam Undang-undang Nomor 20 Tahun 2003 tentang Sistem Pendidikan Nasional pasal 39 ayat (2) menyebutkan pendidik merupakan tenaga profesional yang bertugas merencanakan dan melaksankan proses pembelajaran, menilai hasil pembelajaran, melakukan pembimbingan dan pelatihan. Guru sebagai pendidik adalah orang pertama dan utama dalam meningkatkan mutu pendidikan. Sebagai pelaku utama yang berada di barisan terdepan dalam proses pembelajaran, maka didikan dan bimbingan, yang diberikan guru kepada peserta didik menjadi penentu dalam menghantarkan kesuksesan pendidikan.

Guru harus paham bahwa ia memiliki tugas mendidik, mengajar, membimbing, mengarahkan, melatih, menilai dan mengevaluasi peserta didik sehingga guru dapat melaksanakan fungsi sebagai guru secara tepat, hal demikian menuntut kemampuankajian dan karakteristik siswa agar mencapai hasil yang maksimal. Oleh karena itu peran guru dalam konteks pembelajaran menuntut perubahan antara lain: a). Peran guru sebagai penyebar informasi semakin kecil, tetapi lebih berfungsi sebagai pembimbing, penasehat, dan pendorong. b). Peserta didik adalah individuindividu yang kompleks, yang berarti bahwa mereka mempunyai perbedaan cara belajar dan hal lainnya. c). Proses belajar-mengajar lebih ditekankan pada belajar dari pada mengajar (Laster, 1985).

Salah satu permasalahan pendidikan yang menjadi prioritas pertama untuk segera dipecahkan adalah masalah kualitas pendidikan, khususnya kualitas pembelajaran. Seperti dimaklumi, bahwa sudah sejak lama praktik pembelajaran di Indonesia pada umumnya cenderung dilakukan secara konvensional yaitu melalui teknik komunikasi oral. Praktik pembelajaran konvesional semacam ini lebih cenderung menekankan pada bagaimana guru mengajar (teacher-centered) dari pada bagaimana siswa belajar (student-centered), dan secara keseluruhan hasilnya dapat kita maklumi yang ternyata tidak banyak memberikan kontribusi bagi peningkatan mutu proses dan hasil pembelajaran siswa.

Dalam kaitannya dengan dengan tugas pokok seorang pengawas sekolah, yaitu membimbing, membina, dan evaluasi. Peningkatan kualitas pembelajaran otomatis menjadi tanggung jawab seorang pengawas sekolah.Dalam mengupayakan penerapan hasil training setelah kegiatan inservice teacher training training dalam proses pembelajaran di kelasnya dan mengimbaskan kepada rekanrekan guru di sekolahnya seorang pengawas sekolah harus tetap mengawal proses tersebut agar mendapatkan hasil yang maksimal.

Lesson study dipilih dan dimplementasikan karena beberapa alasan.

Lesson study merupakan suatu cara efektif yang dapat meningkatkan kualitas pembelajaran yang dilakukan guru dan aktivitas belajar siswa. Hal ini karena (1) pengembangan lesson study dilakukan dan didasarkan pada hasil "sharing" pengetahuan profesional yang berlandaskan pada praktik dan hasil pengajaran yang dilaksanakan para guru, (2) penekanan mendasar pada pelaksanaan suatu lesson study adalah agar para siswa memiliki kualitas belajar, (3) kompetensi yang diharapkan dimiliki siswa, dijadikan fokus dan titik perhatian utama dalam pembelajaran di kelas, (4) berdasarkan pengalaman real di kelas, lesson study mampu menjadi landasan bagi pengembangan pembelajaran, dan (5) lesson study akan menempatkan peran para guru sebagai peneliti pembelajaran (Lewis, 2002).

Lesson study yang didisain dengan baik akan menjadikan guru yang profesional dan inovatif. Dengan melaksanakan lesson study para guru dapat (1) menentukan kompetensi yang perlu dimiliki siswa, merencanakan dan melaksanakan pembelajaran (lesson) yang efektif; (2) mengkaji dan meningkatkan pelajaran yang bermanfaat bagi siswa; (3) memperdalam pengetahuan tentang mata pelajaran yang disajikan para guru; (4) 
menentukan standar kompetensi yang akan dicapai para siswa; (5) merencanakan pelajaran secara kolaboratif; (6) mengkaji secara teliti belajar dan perilaku siswa; (7) mengembangkan pengetahuan pembelajaran yang dapat diandalkan; dan (8) melakukan refleksi terhadap pengajaran yang dilaksanakannya berdasarkan pandangan siswa dan koleganya (Lewis, 2002).

Beberapa permasalahan yang ditemukan di sekolah binaan adalah Guru masih sebagai pengajar bukan siswa belajar (masih teachercentered) belum (student- centered). Pembelajaran masih monoton, tidak menyenangkan, serta belum kreatif. Kegiatan inservice teacher training belum diterapkan di kelas atau diimbaskan ke sesama guru.

\section{Metode Penelitian}

Penelitian tindakan sekolah ini dilaksanakan di SMA Swasta Katolik Trisakti Medan, dengan subjek penelitian adalah guru-guru di SMA Swasta Katolik Trisakti Medan. Penelitian ini dibuat dalam dua siklus, dimana setiap siklusnya terdiri dari kegiatan perencanaan, tindakan, observasi, dan refleksi

\section{Siklus pertama.}

\section{a. Perencanaan}

Pada tahap ini, peneliti merencanakan langkah-langkah sebagi berikut:

Menyusun jadwal lesson study. Komponen jadwal meliputi waktu pelaksanaan, guru model (dapat disampaikan dalam bentuk kode), kelas yang menjadi sasaran pelaksanaan lesson study, serta individu yang akan menjadi pengamat (guru sebidang study atau berbeda bidang study). Jadwal disusun berdasarkan kesepakatan antara guru dan pengawas sebagai peneliti. Diupayakan lesson study dapat dilaksanakan sesuai dengan jadwal yang telah ditetapkan. Merencanakan dan menyusun perangkat pembelajaran (plan). Perangkat pembelajaran yang disiapkan di sini meliputi rencana pelaksanaan pembelajaran (RPP), bahan ajar, media pembelajaran/alat peraga, dan alat evaluasi. Perangkat pembelajaran disiapkan oleh guru secara berkelompok (serumpun).
Selanjutnya, hasil perencanaan ini dikonsultasikan kepada pengawas. Konsultasi seyogyanya dilakukan berkali-kali sampai diperoleh perangkat yang layak.

Menyiapkan format-format, deskripsi tugas, serta tata tertib yang diperlukan pada kegiatan lesson study. Format yang disiapkan meliputi format pengamatan, daftar hadir pengamat, angket untuk siswa, tata tertib pelaksanaan. Format ini disusun untuk mendokumentasikan segala kegiatan lesson study sehingga dapat dilakukan refleksi yang akurat. Bahkan, akan lebih baik apabila posisi siswa dan pengamat dalam kelas saat pelaksanaan lesson study juga disiapkan sedemikian rupa pada tahap perencanaan.

\section{b. Pelaksanaan}

\section{Mengikuti kegiatan do}

Kegiatan do yang dimaksud di sini adalah aktivitas guru model (dalam hal ini diperankan oleh salah seorang guru mata pelajaran fisika) dalam melaksanakan pembelajaran sesuai dengan perencanaan (Plan). Dalam kegiatan ini observer mengamati pelaksanaan pembelajarannya. Yang berperan sebagai observer adalah guruguru (dari bidang studi yang sama maupun bidang studi lain), dan pengawas. Proses pengamatan dilakukan dengan menggunakan format pengamatan yang telah disiapkan, dengan memperhatikan tata tertib yang ada.

\section{c. Observasi dan Refleksi}

Mengikuti kegiatan see

Kegiatan ini merupakan kegiatan diskusi formal yang membahas hasil pengamatan terhadap pelaksanaan pembelajaran oleh guru pengajar. Diskusi ini dipimpin oleh seorang moderator dan dibantu oleh notulis. Refleksi yang diawali dengan memberikan kesempatan guru model untuk menyampaikan perasaannya sebelum, saat, dan setelah mengajar ini, dimaksudkan untuk meningkatkan kualitas pembelajaran berikutnya bagi guru model, sekaligus sebagai refleksi diri bagi pengamat. Fokus diskusi diarahkan pada perilaku siswa pada saat pembelajaran berlangsung.

Mengarsipkan semua hasil kegiatan. 
Pengarsipan dilakukan sendiri oleh setiap guru model dalam satu portofolio. Komponen portofolio yang diarsipkan meliputi (1) berita acara pelaksaan lesson study (2) RPP dan perangkat pembelajaran lainnya, (3) lembar pengamatan dari seluruh pengamat, (4) perolehan skor siswa selama pelaksaan lesson study, (5) notulen hasil diskusi, serta (6) foto kegiatan pelaksanaan Lesson Study

2. Siklus kedua, dilaksanakan dengan tahapan yan sama dengan siklus 1 tetapi dengan penyempurnaan sesuai hasil refleksi.

Ada beberapa teknik yang dilakukan dalam pengumpulan data dalam penelitian ini, antara lain : (a) Teknik pengumpulan data: panduan observasi, angket, instrumen penilaian supervisi kelas. Supervisi kelas akhir siklus yang berupa observasi dilaksanakan pada setiap akhir siklus guna mengetahui perubahan yang terjadi di dalam kelas. (b) Sumber data : siswa, guru, peneliti. (c) Instrumen pengumpul data : lembar observasi, lembar angket, foto, instrumen penilaian supervisi akademik. (d) Pelaksanaan observasi : melalui lembar pengamatan pada setiap kegiatan pembelajaran. (e) Pembuatan angket : untuk mengetahui pendapat dan respon guru tentang pembelajaran saintifik.

Penelitian ini menggunakan teknik analisis data secara kualitatif dan kuantitatif, dengan menggunakan teknik persentase. Analisis dan refleksi dilakukan pada setiap akhir pembelajaran dari setiap siklus.Indikator keberhasilan tindakan dalam penelitian ini adalah karakteristik yang ditunjukkan oleh suatu hasil dari tindakan yang dapat membandingkan perubahan nilai atau tingkah laku dari objek yang diteliti. Adapun yang menjadi indikator kinerja sebagai keberhasilan dalam penelitian tindakan kelas ini adalah terjadinya perubahan pada aspek pelaksanaan pembelajaran yang inovatif dan menyenangkan serta peningkatan hasil supervisi kelas secara rata-rata. Hal ini akan dapat dilihat setelah dilakukannya tindakan Apabila indikator keberhasilan tindakan di dalam kelas belum dapat tercapai pada siklus
I maka akan dilanjutkan pada siklus II dan demikian seterusnya hingga pembelajaran sesuai dengan yang diharapkan.

\section{Hasil Penelitian dan Pembahasan}

Pada penelitian ini menggunakan Lesson Study dengan metode diskusi, dimana siswa dilatih untuk aktif berpendapat, menghargai pendapat orang lain, serta menganalisis berbagai opini. Hal ini sesuai dengan karakteristik lesson study yang mengutamakan aktivitas siswa dalam pembelajaran. Penerapan metode diskusi dalam lesson study melalui tahapan plan, do, dan see. Setiap tahapan bertujuan mengarahkan siswa agar belajar dengan senang dan nyaman.

\section{Siklus 1}

Kegiatan dimulai dengan :

\section{PLAN (Perencanaan)}

Menentukan guru model, fasilitator, observer,serta pembimbing lesson study. Menentukan Kompetensi Dasar yang akan diterapkan. Guru model beserta anggota tim menyiapkan RPP, dan jenis diskusi yang akan digunakan. Mempersiapkan segala sesuayu yang dibutuhkan selama proses pembelajaran. Pembimbing memberikan arahan selama merancang pembelajaran

\section{DO (Pelaksanaan)}

Tim melakukan breifing dengan mengecek semua persiapan pembelajaran. Guru model beserta tim memasuki ruangan kelas yang menjadi kelas model. Guru model memulai pembelajaran, dan Observer mengobservasi proses pembelajaran. Guru model menyampaikan tujuan pembelajaran, apersepsi, serta motivasi. Guru model menyampaikan pengantar materi kepada siswa. Guru model membagi siswa kedalam beberapa kelompok. Guru model menyampaikan jenis diskusi dan langkahlangkah yang akan dijalani siswa. Guru model membagi permasalahan/ sub topik kepada setiap kelompok. Masing-masing kelompok mendiskusikan permasalahan yang diberikan oleh guru model. Siswa bertanya kepada guru model terkait materi yang didiskusikan untuk mendapatkan 
penjelasan. Tiap kelompok menganalisis ide yang didiskusikan. Tiap kelompok membuat laporan dan bahan presentase. Masingmasing kelompok mempresentasekan hasil diskusi kepada kelompok lainnya. Terjadi tanya jawab antar kelompok diskusi. Guru model memberikan perbaikan dan memperjelas hasil diskusi yang telah dibahas dan dipresentasekan. Observer mengamati dan mencatat semua aktivitas dalam proses pembelajaran.

\section{SEE (Refleksi)}

Kegiatan ini dilakukan di dalam ruangan khusus dan dilakukan setelah kegiatan DO, yang dimulai dengan : Guru model menyampaikan kesan selama proses pembelajaran. Observer menyampaikan hasil pengamatannya. Aktivitas siswa didiskusikan oleh tim lesson study, baik yang mendukung pembelajaran (bersifat positif), maupun yang tidak mendukung pembelajaran (bersifat negatif). Tim menganalisis berbagai aktivitas siswa selama pembelajaran. Tim mendiskusikan solusi dari kekurangan siswa selama proses pembelajaran. Semua anggota tim mencatat segala hal dalam diskusi. Hasil diskusi disiapkan untuk siklus berikutnya.

Dari hasil Plant, Do, See diperoleh data sebagai berikut : Instrumen Observasi Pelaksanaan Pembelajaran untuk Guru seperti pada Tabel 1 .

Tabel 1. Persentase perolehan nilai pelaksanaan pembelajaran guru pada siklus 1

\begin{tabular}{llcccc}
\hline No & Kegiatan/Unsur & Jumlah Item & Skor maks & $\begin{array}{l}\text { Persentase } \\
\text { tiap kegiatan (\%) }\end{array}$ & $\begin{array}{l}\text { Persentase } \\
\text { Perolehan (\%) }\end{array}$ \\
\hline 1 & Pendahuluan & 4 & 12 & 20 & 75,00 \\
\hline 2 & Isi & 10 & 30 & 50 & 86,67 \\
\hline 3 & Penutup & 4 & 12 & 20 & 91,67 \\
\hline 4 & Penampilan & 2 & 6 & 10 & 83,33 \\
\hline & Jumlah & 20 & 60 & 100 & \\
\hline
\end{tabular}

Hasil di atas dapat juga ditampilkan dalam bentuk diagram batang berikut.

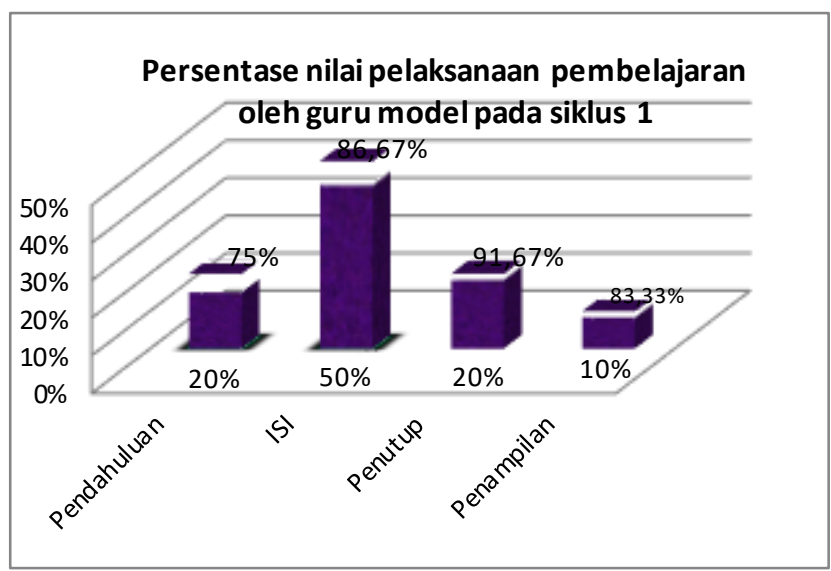

Gambar 1. Diagram batang pelaksanaan pembelajaran pada siklus 1 .
Hasil observasi terhadap aktivitas siswa saat pembelajaran dapat dilihat seperti pada Tabel 2 berikut.

Tabel 2. Pengamatan aktivitas siswa

\begin{tabular}{clcc}
\hline NO & $\begin{array}{l}\text { Kegiatan yang } \\
\text { diobservasi }\end{array}$ & $\begin{array}{c}\text { Jumlah siswa } \\
\text { yang } \\
\text { melakukan }\end{array}$ & $\begin{array}{l}\text { Persentase } \\
(\%)\end{array}$ \\
\hline 1 & $\begin{array}{l}\text { Merespon } \\
\text { pertanyaan/ } \\
\text { pernyataan }\end{array}$ & 69,44 \\
\hline 2 & $\begin{array}{l}\text { Mengajukan } \\
\text { pertanyaan/ } \\
\text { pernyataan }\end{array}$ & 23 orang & 63,89 \\
\hline 3 & $\begin{array}{l}\text { Aktif dalam diskusi } \\
\text { kelompok }\end{array}$ & 28 orang & 77,78 \\
\hline 4 & $\begin{array}{l}\text { Dapat } \\
\text { mengomunikasikan } \\
\text { hasil yang diperoleh }\end{array}$ & 30 orang & 83,33 \\
\hline
\end{tabular}

Dari tabel di atas, diperoleh aktivitas siswa paling bagus adalah mampu mengkomunikasikan hasil diskusi mereka 
dengan jumlah 30 orang atau 83,33\%, kemudian diikuti dengan keaktifan dalam diskusi sebesar $77,78 \%$, dengan rata-rata aktivitas 73,63\%.

\section{Siklus 2}

Hasil siklus 1 belum memadai maka berdasarkan hasil SEE pertama tim kembali merancang Plan untuk siklus kedua dengan langkah-langkah kegiatan yang sama.

\section{PLAN (perencanaan)}

Kegiatan yang dilakukan tim sama dengan pada saat plan 1, tetapi dengan catatan guru model, observer, fasilitator, dan pembimbing sama dengan pada saat siklus 1 . Menentukan Kompetensi Dasar yang akan diterapkan. Guru model beserta anggota tim menyiapkan RPP, dan jenis diskusi yang akan digunakan. Dalam hal ini dilakukan penyempurnaan RPP. Mempersiapkan segala sesuatu yang dibutuhkan selama proses pembelajaran. Pembimbing memberikan arahan selama merancang pembelajaran.

\section{DO (pelaksanaan)}

Langkah-langkah kegiatan yang yang dilakukan sama dengan langkah-langkah kegiatan pada DO 1, tetapi dengan perbaikan disana-sini antara lain : Tim melakukan breifing dengan mengecek semua persiapan pembelajaran. Guru model beserta tim memasuki ruangan kelas yang menjadi kelas model. Guru model memulai pembelajaran, dan Observer mengobservasi proses pembelajaran. Guru model menyampaikan tujuan pembelajaran, apersepsi, serta motivasi (guru model agar lebih spesifik dan terarah). Guru model menyampaikan pengantar materi kepada siswa (materi yang akan dipelajari telah diinformasikan pada kepada siswa pada pertemuan sebelumnya). Guru model membagi siswa kedalam beberapa kelompok. Guru model menyampaikan jenis diskusi dan

Tabel 3. Persentase perolehan nilai pelaksanaan pembelajaran guru pada siklus 1

\begin{tabular}{llllll}
\hline \multirow{2}{*}{ No } & \multirow{2}{*}{ Kegiatan/Unsur } & \multirow{2}{*}{ Jumlah Item } & $\begin{array}{l}\text { Skor } \\
\text { Maksimum }\end{array}$ & $\begin{array}{l}\text { Persentase tiap } \\
\text { Kegiatan }(\%)\end{array}$ & $\begin{array}{l}\text { Persentase } \\
\text { Perolehan }(\%)\end{array}$ \\
\hline 1 & Pendahuluan & 44 & 112 & 20 & 91,67 \\
\hline 2 & Isi & 110 & 330 & 50 & 93,33 \\
\hline 3 & Penutup & 44 & 112 & 20 & 100,00 \\
\hline 4 & Penampilan & 22 & 66 & 10 & 83,33 \\
\hline 5 & Jumlah & 220 & 660 & 100 & \\
\hline
\end{tabular}

langkah-langkah yang akan dijalani siswa. (Guru model menentukan tugas masingmasing siswa didalam kelompoknya). Guru model membagi permasalahan/ sub topik kepada setiap kelompok. Masing-masing kelompok mendiskusikan permasalahan yang diberikan oleh guru model. Siswa bertanya kepada guru model terkait materi yang didiskusikan untuk mendapatkan penjelasan. Tiap kelompok menganalisis ide yang didiskusikan. Tiap kelompok membuat laporan dan bahan presentase. Masingmasing kelompok mempresen- tasekan hasil diskusi kepada kelompok lainnya. Terjadi tanya jawab antar kelompok diskusi. Guru model memberikan perbaikan dan memperjelas hasil diskusi yang telah dibahas dan dipresentasekan. Observer mengamati dan mencatat semua aktivitas dalam proses pembelajaran.

\section{SEE (Refleksi)}

Kegiatan ini dilakukan di dalam ruangan khusus dan dilakukan setelah kegiatan DO, yang dimulai dengan : Guru model menyampaikan kesan selama proses pembelajaran. Observer menyampaikan hasil pengamatannya. Aktivitas siswa didiskusikan oleh tim lesson study, baik yang mendukung pembelajaran (bersifat positif), maupun yang tidak mendukung pembelajaran (bersifat negatif). Tim menganalisis berbagai aktivitas siswa selama pembelajaran. Tim mendisdusikan solusi dari kekurangan siswa selama proses pembelajaran. Semua anggota tim mencatat segala hal dalam diskusi. Hasil diskusi disiapkan untuk plan (bila diperlukan)

Dari hasil Plant, Do, See pada siklus 2 diperoleh nilai pelaksanaan pembelajaran guru seperti pada Tabel 3 berikut. 
Hasil di atas dapat juga ditampilkan dalam bentuk diagram batang berikut.

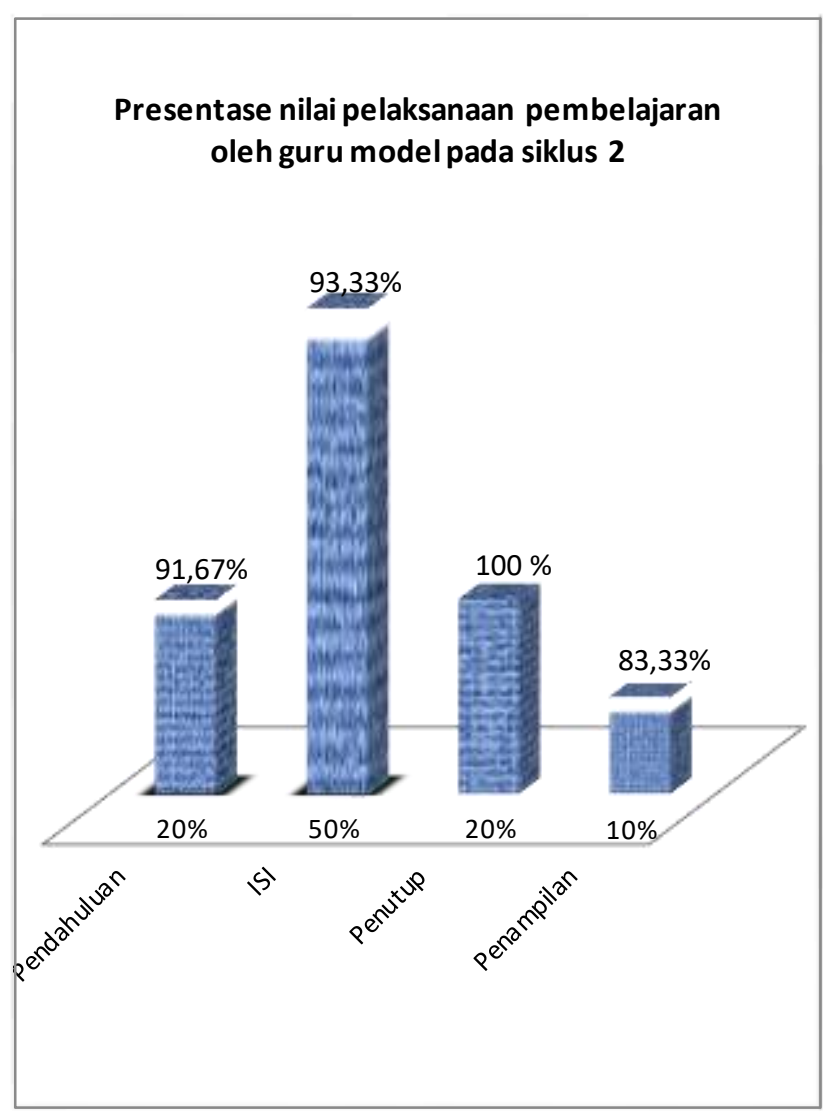

Gambar 2. Diagram batang pelaksanaan pembelajaran pada siklus 2 .

Dari Tabel 1 dapat dilihat bahwa pelaksanaan pembelajaran oleh guru model di dalam penilaian pendahuluan, isi, penutup dan penampilan, dimana pendahuluan diberikan persentase $20 \%$ memiliki nilai sebesar $75 \%$ pada siklus 1 menjadi 91,67\% pada siklus 2 . Hal ini guru model telah menguasai pelaksanaan pembelajaran dengan model Lesson study ini, karena guru telah memahami dan menyadari pentingnya pendahualan dalam pembelajaran untuk memotivasi siswa untuk rasa ingin tahu terhadap topik yang ingin dipelajari. Dari segi isi pelajaran, guru telah menguasai isi topik yang diberikan dan disampaikan dengan baik.
Hasil observasi terhadap aktivitas siswa saat pembelajaran dapat dilihat seperti pada Tabel 4 berikut.

Tabel 4. Pengamatan aktivitas siswa pada siklus 2

\begin{tabular}{clcc}
\hline No & $\begin{array}{l}\text { Kegiatan yang } \\
\text { diobservasi }\end{array}$ & $\begin{array}{c}\text { Jumlah } \\
\text { siswa yang } \\
\text { melakukan }\end{array}$ & $\begin{array}{l}\text { Persentase } \\
(\%)\end{array}$ \\
\hline 1 & $\begin{array}{l}\text { Merespon } \\
\text { pertanyaan/ } \\
\text { pernyataan }\end{array}$ & 30 orang & 83,33 \\
\hline 2 & $\begin{array}{l}\text { Mengajukan } \\
\text { pertanyaan/ } \\
\text { pernyataan }\end{array}$ & 28 orang & 77,78 \\
\hline 3 & $\begin{array}{l}\text { Aktif dalam } \\
\text { diskusi } \\
\text { kelompok }\end{array}$ & 32 orang & 88,89 \\
\hline 4 & $\begin{array}{l}\text { Dapat } \\
\text { mengomunikasi } \\
\text { kan hasil yang } \\
\text { diperoleh }\end{array}$ & 32 orang & 88,89 \\
\hline & & \\
\hline
\end{tabular}

Dari tabel di atas, dapat dilihat peningkatan aktivitas siswa dari siklus 1 ke siklus 2 . Dimana pada siklus 2 ini, sudah memiliki rata-rata aktivitas sebesar $84,72 \%$ sedangkan pada siklus 1 sebesar $73,63 \%$. Jadi ada peningkatan aktivitas sebesar $11,09 \%$. Respon siswa terhadap pertanyaan/pernyataan juga meningkat dari $69,44 \%$ menjadi $83,33 \%$, hal ini dapat terjadi karena guru selalu memotivasi siswa untuk berani memberi tanggapan terhadap pertanyaan siswa dan guru lebih sabar menunggu jawaban dari siswa. Demikian juga halnya dalam mengajukan pertanyaan terjadi peningkatan dari $63,89 \%$ menjadi $77,78 \%$. Keaktifan siswa dalam diskusi kelompok juga meningkat dari $77,78 \%$ menjadi $88,89 \%$ dan dalam mengkomunikasikan hasil diskusi juga meningkat dari $83,33 \%$ menjadi $88,89 \%$. Hal ini dapat terjadi karena guru selalu membimbing mereka dalam melaksanakan tugas-tugasnya, sehingga selalu aktif dalam belajar dan mau berubah sesuai arahan dari guru. 


\section{Simpulan dan Saran}

Kegiatan lesson study dapat berhasil meningkatkan profesionalitas guru, tidak terlepas dari kadar partisipasi guru sendiri dalam kegiatan tersebut. Peran guru dalam melakukan lesson study harus menunjukkan komitmen yang tinggi, terbuka dalam menerima masukan, selalu berupaya untuk memperbaiki diri secara kontinu, selalu menunjukkan kinerja terbaik untuk meningkatkan kemampuan dalam mengelolah pembelajaran, dan mampu bekerja kolaboratif semua pihak yang berpartisipasi dalam lesson study .

Pelaksanaan lesson study juga menjadi menjadi salah satu faktor yang mendorong guru untuk mencoba metode-metode pembelajaran yang dapat menciptakan pembelajaran yang inovatif dan menyenangkan.

Agar kegiatan lesson study terlaksana sesuai rencana diharapkan peran serta dan dukungan penuh dari seluruh warga sekolah serta pengawas sekolah baik dalam menyediakan fasilitas berupa media pembimbingan, maupun dukungan waktu dan moril. Kepada pengawas sekolah (supervisor) diharapkan dapat melakukan penilitian lebih lanjut untuk penerapan pada situasi dan kondisi yang berbeda. Kegiatan lesson study sangat disarankan untuk guru, kepala sekolah, dan pengawas sebagai kegiatan team work guna meningkatkan mutu pembelajaran.

\section{Daftar Pustaka}

Arends, R., (2008), Learning To Teach, Pustaka Pelajar, Yogyakarta.

Hamalik, O. 2010. Proses Belajar Mengajar, Bumi Aksara, Jakarta.

Istarani. 2012. 58 Model Pembelajaran Inovatif, Media Persada, Medan,

Rusman. 2014. Model-Model Pembelajaran, Karisma Putra, Bandung.

Slameto. 2010. Belajar Dan Faktor-Faktor Yang Mempengaruhinya, Rineka Cipta, Jakarta.

Slavin., 2009, Cooperatif Learning, Nusa Media, Bandung.

Sudjana., 2005, Metoda Statistika, Tarsito, Bandung.

Sugiono., 2008, Metode Penelitian Pendidikan, Alfabeta, Bandung.

Suprijono, A. 2009. Cooverative Learning. Pustaka Insan Madani. Yogyakarta.

Syah, M. 2010. Psikologi Pendidikan. Rosdakarya, Bandung.

Trianto. 2009. Mendesain Model Pembelajaran Inovatif-Progresif. Kencana, Jakarta. 